\title{
APLIKASI PETA JENIS TANAH DALAM MENGIDENTIFIKASI LAHAN BERPOTENSI UNTUK PERKEBUNAN KELAPA SAWIT DI KECAMATAN CENDANA KABUPATEN ENREKANG
}

\author{
Hasriyanti $^{1}$, Ibrahim Abbas ${ }^{2}$, M. Nur Zakariah Leo ${ }^{2}$ \\ E-mail: yantisakijo@yahoo.com
}

\begin{abstract}
Abstrak: Tujuan penelitian ini adalah untuk memberikan informasi menyeluruh kepada masyarakat di Kecamatan Cendana mengenai potensi lahan setempat untuk perkebunan kelapa sawit. Masyarakat diharapkan mampu mengidentifikasi wilayah-wilayah mana yang cocok dijadikan perkebunan sawit. wilayahwilayah mana yang cocok dijadikan perkebunan sawit berdasarkan interpretasi peta jenis tanah. Langkah yang ditempuh dalam memecahkan masalah pada kegiatan ini adalah sebagai berikut: a) melakukan kerjasama dengan Instansi terkait di Kecamatan Cendana Kabupaten Enrekang, yakni Kepala Kecamatan serta tokoh masyarakat dan para warga setempat dalam pengenalan penggunaan lahan yang ada di Kecamatan Cendana, b) melakukan kegiatan pendataan dan pengenalan dalam mengidentifikasi beberapa permasalahan penggunaan lahan yang terdapat di sekitar wilayah penelitian, agar mampu disinergiskan dengan tujuan atau sasaran dari pelaksanaan kegiatan pengabdian kepada masyarakat, c) melakukan praktik aplikasi peta tematik, dalam hal ini peta jenis tanah, untuk keperluan identifikasi wilayah berpotensi untuk perkebunan kelapa sawit. Hasil yang diperoleh dalam kegiatan ini menunjukkan bahwa ada sebagian besar lahan berpotensi cocok untuk budidaya kelapa sawit di Kecamatan Cendana Kabupaten Enrekang. Lanjut pada beberapa data yang menunjukkan bahwa pengetahuan masyarakat masih sangat kurang mengenai potensi lahan terhadap perkebunan kelapa sawit. Hal tersebut ditunjukkan dengan jumlah dan luasan lahan perkebunan kelapa sawit yang sedikit terdapat di Kecamatan Cendana, kondisi lahan yang tidak terawat baik meskipun sudah ditanami kelapa sawit. Masyarakat melalui pemerintah setempat, diberikan pengetahuan melalui aplikasi peta tematik jenis tanah dalam mengidentifikasi lahan berpotensi untuk perkebunan kelapa sawit. Meskipun kegiatan ini hanya sebatas pada identifikasi sebagai tahap awal, diharapkan selanjutnya dilakukan penelitian melalui parameter fisik, kimia, dan biologinya secara mendalam.
\end{abstract}

Kata-kata kunci: Aplikasi Peta Jenis Tanah, Identifikasi Lahan, Kelapa Sawit

\section{PENDAHULUAN}

Lahan merupakan sumber daya alam yang sangat penting untuk pengembangan usaha perkebunan, terutama untuk memenuhi kebutuhan sandang dan pangan. Permasalahan dalam penggunaan lahan sifatnya umum di seluruh dunia, baik di

\footnotetext{
${ }^{1}$ Dosen Universitas Negeri Makasar

${ }^{2}$ Dosen Universitas Negeri Makasar

${ }^{3}$ Dosen Universitas Negeri Makasar
}

negara sedang berkembang maupun negara maju, terutama akan menjadi menonjol bersama dengan terjadinya peningkatan jumlah penduduk dan proses industrialisasi. 
Meningkatnya kebutuhan dan persaingan dalam penggunaan lahan baik untuk keperluan produksi perkebunan maupun untuk keperluan lainnya memerlukan pemikiran yang seksama dalam mengambil keputusan yang paling menguntungkan dari sumber daya lahan yang terbatas. Disamping itu perlu juga melakukan tindakan konservasi untuk penggunaan yang berkelanjutan (Rahman, 1995).

Lahan kering di Indonesia pada umumnya adalah Aluvial yang tersebar luas di daerah Sumatera, Kalimantan, Sulawesi dan Irian Jaya. Aluvial sering dijumpai dari dataran rendah di sepanjang aliran sungai, rawa air tawar, pasang surut teras sungai, sampai daerah dengan ketinggian mencapai 1000 meter di atas permukaan laut, sepanjang lembah-lembah aliran sungai di pegunungan. Bila drainase air sempurna maka tanah ini sangat produktif (Hakim et al., 1986). Untuk dapat melakukan perencanaan secara menyeluruh, salah satu masukan yang diperlukan adalah tersedianya informasi aktual mengenai faktor fisik lingkungan yang meliputi sifat-sifat dan potensial lahan. Keterangan tersebut dapat diperoleh antara lain melalui kegiatan survai tanah yang diikuti analisa laboratorium dan evaluasi sumber daya lahan.

Salah satu penggunaan lahan adalah untuk tanaman kelapa sawit (Alaeis). Kelapa sawit (Elaeis) adalah tumbuhan industri penting penghasil minyak masak, minyak industri, maupun bahan bakar (biodiesel). Perkebunannya menghasilkan keuntungan besar sehingga banyak hutan dan perkebunan lama dikonversi menjadi perkebunan kelapa sawit. Indonesia adalah penghasil minyak kelapa sawit terbesar di dunia. Penyebarannya di daerah
Aceh, pantai timur Sumatra, Jawa, Kalimantan, dan Sulawesi.

Pemerintah Kabupaten Enrekang menyiapkan lahan seluas 400 hektar yang terletak di Kecamatan Maiwa dan Kecamatan Cendana untuk pengembangan perkebunan kelapa sawit. Saat ini telah ada beberapa Investor yang menyatakan berminat berinverstasi. Pemerintah Daerah telah melakukan sosialisasi kepada masyarakat terkait pengelolaan lahan warga untuk dijadikan perkebunan kelapa sawit, dan hasilnya lahan Kecamatan Cendana memang memiliki potensi yang dapat dikembangkan menjadi salah satu perkebunan kelapa sawit, kedepannya perkebunan ini jika terealisasi akan sangat menjanjikan.

Setelah melakukan survey teknis, langkah selanjutnya adalah melakukan survey sosial kemasyarakatan. Fungsinya untuk mengetahui sejauh mana tanggapan masyarakat terkait rencana perkebunan kelapa sawit. Hasil survey kemasyarakatan nantinya dapat dijadikan pertimbangan jadi tidaknya ataupun mau tidaknya masyarakat, termasuk besaran ganti rugi yang layak diterima masyarakat. Pelaksanaan survey tersebut tentu saja menggunakan peta jenis tanah yang akan disosialisasikan kepada masyarakat setempat mengenai kecocokan lahan yang diidentifikasi untuk perkebunan kelapa sawit.

Kecamatan Cendana memiliki potensi lahan untuk perkebunan kelapa sawit. Masyarakat setempat belum banyak mengetahui lahan-lahan berpotensi yang berada di wilayah mereka. Aplikasi peta tematik tentunya akan sangat mendukung pengetahuan warga dalam mengidentifikasi lahan setempat untuk keperluan perkebunan kelapa sawit. Peta tematik yang 
14

Hasriyanti, Ibrahim Abbas, M. Nur Zakariah Leo. Aplikasi Peta Jenis Tanah Dalam

Mengidentifikasi Lahan Berpotensi Untuk Perkebunan Kelapa Sawit Di Kecamatan Cendana

Kabupaten Enrekang

dimaksud di sini adalah peta jenis tanah

Kecamatan Cendana, sehingga dengan mengetahui dan memahami jenis tanah wilayah setempat, maka warga dapat mengidentifikasi dengan baik serta mengetahui dimana-mana saja letak atau posisi wilayah yang berpotensi untuk perkebunan kelapa sawit. Berdasarkan latar belakang yang telah dikemukakan, maka masalah yang akan diteliti adalah bagaimana tingkat pengetahuan warga dan pemerintah di Kecamatan Cendana mengenai potensi lahan yang ada untuk perkebunan kelapa sawit.

\section{METODE PENELITIAN}

Bentuk kegiatan untuk memecahkan masalah adalah dengan melakukan kegiatan pengumpulan data dan informasi, baik yang berbentuk teori maupun praktek melalui media peta tematik. Masyarakat lokal diharapkan mampu menjadi pemandu dalam menunjang informasi penggunaan lahan pada wilayahnya sendiri untuk keperluan perkebunan. Peningkatan dalam bidang perkebunan tentunya dapat menambah pendapatan daerah tertentu dalam kurun waktu tertentu jika dikelola dengan baik dan mengembangkan informasi melalui peta tematik.

Adapun langkah-langkah yang ditempuh dalam memecahkan masalah pada kegiatan ini adalah sebagai berikut:

1). Melakukan kerjasama dengan Instansi terkait di Kecamatan Cendana Kabupaten Enrekang, yakni Kepala Kecamatan serta tokoh masyarakat dan para warga setempat dalam pengenalan penggunaan lahan yang ada di Kecamatan Cendana.
2). Melakukan kegiatan pendataan dan pengenalan dalam mengidentifikasi beberapa permasalahan penggunaan lahan yang terdapat di sekitar wilayah penelitian, agar mampu disinergiskan dengan tujuan atau sasaran dari pelaksanaan kegiatan pengabdian kepada masyarakat.

3). Melakukan praktek aplikasi peta tematik, dalam hal ini peta jenis tanah, untuk keperluan identifikasi wilayah berpotensi untuk perkebunan sawit di Kecamatan Cendana Kabupaten Enrekang. Peta jenis tanah yang dianalisis yakni peta jenis tanah skala kabupaten seperti yang terlihat pada gambar 1 . 


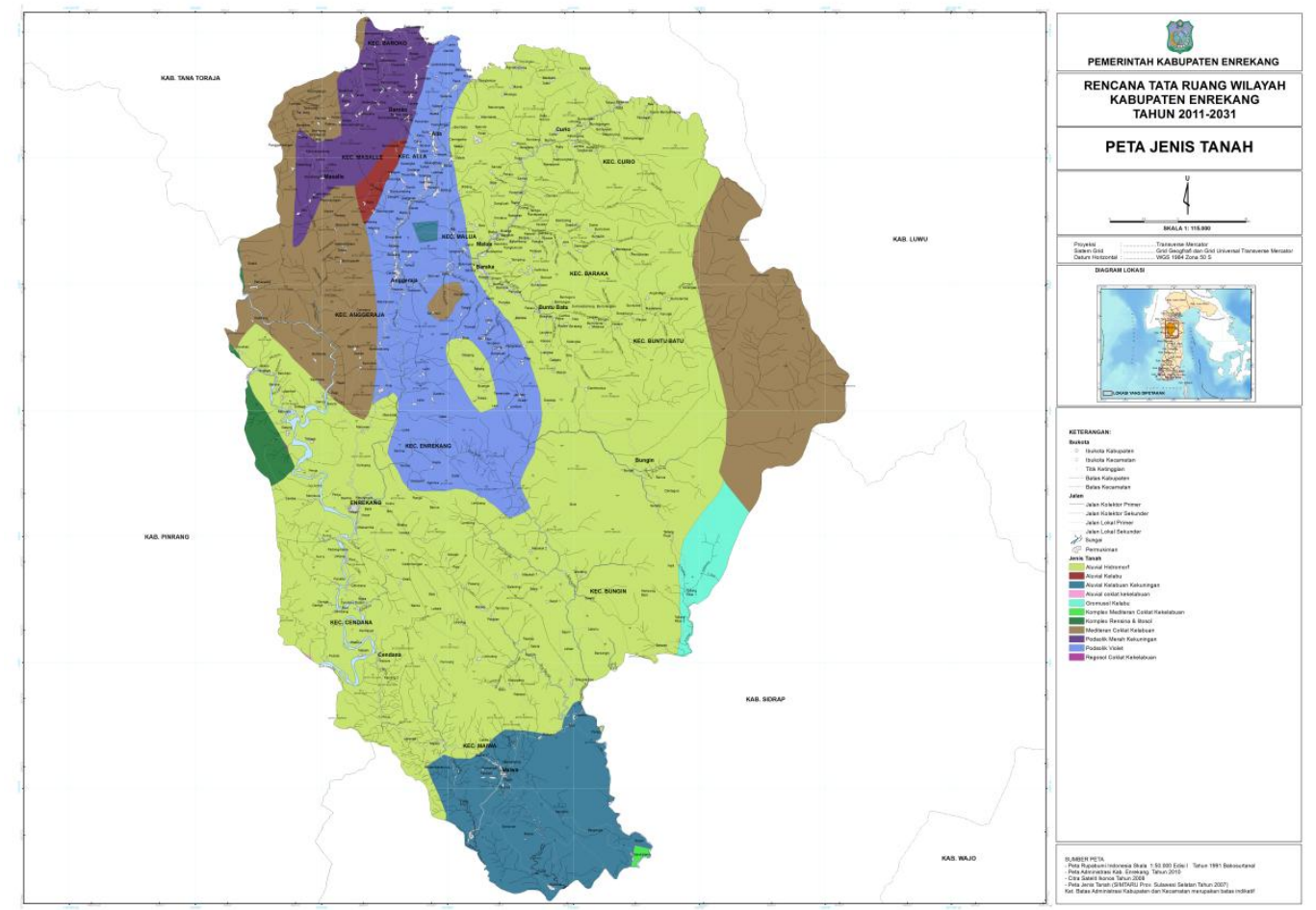

Gambar 1. Peta Jenis Tanah Skala Kabupaten

\section{HASIL DAN PEMBAHASAN}

Penyebaran jenis dan karakter tanah di suatu daerah, biasanya disusun dalam suatu bentuk Peta Tanah. Peta ini sangat berguna bagi para petani dan telah disusun berdasarkan hasil penelitian dan pengamatan langsung (observasi) di lapangan. Para pengambil kebijakan sebaiknya mempertimbangkan pula penyebaran jenis tanah berdasarkan Peta Tanah yang telah dibuat. Jangan sampai suatu wilayah dengan potensi tanah dapat menghasilkan produk pertanian unggulan, malah dijadikan lokasi perdagangan dalam master plannya. Peta Tanah dibuat secara berjenjang, misalnya Peta Tanah seluas wilayah kabupaten atau kecamatan.

\footnotetext{
${ }^{1}$ Dosen Universitas Negeri Makasar

${ }^{2}$ Dosen Universitas Negeri Makasar

${ }^{3}$ Dosen Universitas Negeri Makasar
}

\section{Analisis Manfaat}

Penampakan wilayah permukaan bumi yang disajikan dalam bentuk peta dapat difungsikan untuk berbagai keperluan, salah satunya ialah untuk keperluan budidaya pertanian. Dengan menggunakan analisis peta, kita akan mudah menentukan daerah atau wilayah mana saja yang cocok untuk dijadikan lahan pertanian, serta jenis komoditas pertanian apa sajakah yang cocok pula di wilayah pertanian tersebut. Oleh sebab itu, untuk menjawab kedua pertanyaan tadi diperlukan analisis variabel yang terdapat dalam kompilasi peta yang berhubungan dengan aspek pertanian tersebut. Sebagai contoh, untuk menentukan wilayah yang cocok dijadikan perkebunan kelapa sawit, 
Hasriyanti, Ibrahim Abbas, M. Nur Zakariah Leo. Aplikasi Peta Jenis Tanah Dalam Mengidentifikasi Lahan Berpotensi Untuk Perkebunan Kelapa Sawit Di Kecamatan Cendana Kabupaten Enrekang

maka sebagai bahan pertimbangan awal diperlukan letak ketinggian wilayah tersebut dari peta topografi atau peta rupa bumi. Apabila ditemukan letak ketinggian antara 400-1000 m dpl, maka sangat cocok untuk dijadikan lahan perkebunan sawit karena pada ketinggian tersebut tanaman holtikultura dapat hidup dan berkembang.

Selanjutnya untuk menentukan jenis tanaman holtikutura yang cocok untuk ditanam, maka dalam hal ini diperlukan informasi yang lebih detail lagi yang diperoleh dari berbagai peta tematik, seperti peta tanah, peta curah hujan, peta geologi, dan sebagainya.

Dengan demikian, dari contoh kasus di atas, kita bisa menarik kesimpulan bahwa keberadaan peta dapat diberdayakan untuk kepentingan pertanian. Adapun analisis peta yang menyangkut aspek pertanian antara lain:

1). Peta topografi/rupa bumi, untuk melihat ketinggian suatu wilayah, karena dengan melihat ketinggian dapat diperoleh pula data mengenai potensi curah hujan dan suhu yang berpengaruh terhadap aspek pertanian. Dari peta ini dapat diperoleh pula informasi tentang kemiringan lereng yang terdapat di suatu wilayah.

2). Peta tanah, untuk melihat jenis tanah yang ada sehingga dapat dijadikan acuan dalam menentukan jenis tanaman apa yang sesuai dengan kondisi tanahnya (struktur, tekstur, dan kelembaban).

3). Peta geologi, untuk melihat karakteristik batuan di sekitar wilayah pertanian. Dari peta ini dapat diperoleh data tentang permeabilitas batuan yang erat kaitannya dengan kemampuan dalam meloloskan air.

\section{Rangkaian Proses}

Peta jenis tanah Kabupaten Enrekang telah dianalisis berdasarkan kegiatan plotting lokasi dan interpretasi peta di lapangan. Hasil plotting lokasi menemukan titik atau dot pada sebuat peta tematik jenis tanah tempat dilakukannya kegiatan pengabdian kepada masyarakat.

Berdasarkan peta jenis tanah Kabupaten Enrekang, diperoleh bahwa jenis tanah Kecamatan Cendana adalah jenis tanah Aluvial Hidromorf, dimana jenis tersebut juga dapat dilihat pada sebagian besar wilayah Kecamatan Bungin, Kecamatan Buntubatu, Kecamatan Baraka, dan Kecamatan Curio, serta sebagian kecil jenis tanah tersebut dapat ditemukan di Kecamatan Enrekang dan Kecamatan Maiwa.

\section{Kesesuaian Lahan Kelapa Sawit}

Berdasarkan referensi yang dikutip dari Sunarko (2007), kesesuaian lahan Kelapa sawit dapat tumbuh di berbagai jenis tanah, seperti tanah podsolik, latosol, hidromorfik kelabu, regosol, andosol, dan alluvial. Tanah gambut juga dapat ditanami kelapa sawit asalkan ketebalan gambutnya tidak lebih dari satu meter dan sudah tua (saphrik). Hal tersebut sesuai dengan hasil analisis yang dilakukan dalam interpretasi peta tematik jenis tanah di Kecamatan Cendana. Sifat tanah yang perlu di perhatikan untuk budidaya kelapa sawit adalah sebagai berikut:

\section{Sifat Fisik Tanah}


Tanaman kelapa sawit dapat tumbuh baik di tanah yang bertekstur lempung berpasir, tanah liat berat, tanah gambut memiliki ketebalan tanah lebih dari 75 $\mathrm{cm}$; dan berstruktur kuat.

\section{Sifat Kimia Tanah}

Tanaman kelapa sawit membutuhkan unsur hara dalam jumlah besar untuk pertumbuhan vegetatif dan generatif. Untuk mendapatkan produksi yang tinggi dibutuhkan kandungan unsur hara yang tinggi juga. Selain itu, $\mathrm{pH}$ tanah sebaiknya bereaksi dengan asam dengan kisaran nilai 4,0 - 6,0 dan ber $\mathrm{pH}$ optimum 5,0 - 5,5.

\section{Keadaan Iklim}

Keadaan iklim sangat memengaruhi proses fisiologi tanaman, seperti proses asimilasi, pembentukan bunga, dan pembuahan. Sinar matahari dan hujan dapat menstimulasi pembentukan bunga kelapa sawit. Jumlah curah hujan dan lamanya penyinaran matahari memiliki korelasi dengan fluktuasi produksi kelapa sawit. Curah hujan ideal untuk tanaman kelapa sawit adalah 2.000-2.500 mm per tahun dan tersebar merata sepanjang tahun. Jumlah penyinaran rata rata sebaiknya tidak kurang dari 6 jam per hari. Temperature sebaiknya $22-23^{\circ}$. Angin tidak terlalu berpengaruh karena kelapa sawit lebih tahan terhadap angin kencang dibandingkan tanaman lainnya. Bulan kering yang tegas dan berturut-turut selama beberapa bulan bisa mempengaruhi pembentukan bunga baik jantan maupun seks rasionya untuk 2 tahun berikutnya.

\section{Karakteristik Jenis Tanah Aluvial Hidromorf}

Jenis tanah aluvial hidromorf ini masih muda, belum mengalami pengembangan, berasal dari abahn induk aluvium, tekstur beraneka ragam, belum terbentuk tekstur, konsistensi dalam keadaan basah lekat, PH bermacam-macam, kesuburan sedang hingga tinggi. Tanah aluvial hanya meliputi lahan yang sering atau baru saja mengalami banjir, sehingga dapat dianggap masih muda dan belum ada diferensiasi horison. Endapan aluvial yang sudah tua dan menampakkan akibat pengaruh iklim dan vegetasi tidak termasuk aluvial.

Kebanyakan tanah aluvial sepanjang aliran besar merupakan campuran mengandung cukup banyak unsur hara tanaman, sehingga umumnya dianggap tanah subur sejak dulu. Jenis tanah aluvial dapat dibedakan lagi atas dasar warnanya seperti tanah aluvial hidromorf, aluvial kelabu, aluvial coklat dan lain-lain. Jenis tanah ini mempunyai ciri-ciri fisik warna kelabu, bertekstur liat, dan memiliki permiabilitas (water run off) lambat. Jenis tanah ini biasanya banyak digenangi air sehingga warnanya tua kelabu sampai kehitaman. Daerah penyebarannya terdapat di berbagai ketinggian tetapi umumnya di dataran rendah dengan daerah relatif datar sampai bergelombang.

Aluvial Hidromorf Kelabu (Gleisol) merupakan tanah mineral yang mempunyai perkembangan khusus sebagai akibat sebagian besar profil tanah dalam kondisi anaerob. Gleisol mempunyai rentang sifat: solum tanah sedang warna kelabu hingga kekuningan, tekstur geluh hingga lempung, struktur berlumpur hingga masif, konsistensi lekat, bersifat asam, kandungan bahan organik tinggi. Ciri khas tanah ini adanya lapisan glei menerus 
Hasriyanti, Ibrahim Abbas, M. Nur Zakariah Leo. Aplikasi Peta Jenis Tanah Dalam Mengidentifikasi Lahan Berpotensi Untuk Perkebunan Kelapa Sawit Di Kecamatan Cendana Kabupaten Enrekang

yang berwarna kelabu pucat pada kedalaman kurang dari 0,5 $\mathrm{m}$ akibat dari profil tanah selalu jenuh air.

Jenis tanah ini perkembangannya lebih dipengaruhi oleh faktor lokal, yaitu topografi merupakan dataran rendah atau cekungan, hampir selalu tergenang air, solum tanah sedang, warna kelabu hingga kekuningan, tekstur geluh hingga lempung, struktur berlumpur hingga masif, konsistensi lekat, bersifat asam $(\mathrm{pH} 4.5$ 6.0 ), kandungan bahan organik.

\section{Langkah Pencocokan}

\section{Identifikasi Peta}

Hasil dari Langkah 1 adalah peta potensi kecocokan lahan, yang menggolongkan semua lahan ke dalam salah satu dari tiga kelas kecocokan untuk ekspansi kelapa sawit berkelanjutan: berpotensi tinggi, berpotensi, atau tidak cocok. Peta kecocokan gabungan ini adalah kombinasi tiga lapisan tematik, masing-masing terkait dengan salah satu pertimbangan berikut: tematik iklim, tematik geologi dan tematik jenis tanah. Dalam hal ini kegiatan hanya difokuskan pada kegiatan identifikasi semata, belum pada analisis tingkat tinggi untuk kesesuaian lahan kelapa sawit berkelanjutan. Identifikasi peta menemukan bahwa tingkat kecocokan berada pada kondisi berpotensi cocok sebagai lahan perkebunan sawit di Kecamatan Cendana. Didukung oleh sudah adanya beberapa perkebunan kelapa sawit yang berada di lokasi kegiatan, dengan kondisi tanaman yang subur meskipun masih dalam jumlah yang sedikit. Kondisi belukar yang masih sangat banyak tumbuh di sekitar tanaman kelapa sawit, menandakan bahwa kurang terawatnya perkebunan kelapa sawit yang ada di Kecamatan Cendana, sehingga memunculkan pemikiran bahwa pengetahuan masyarakat mengenai budidaya dan pemeliharaan kelapa sawit masih sangat minim.

\section{Pemilihan Lokasi Survei Lapangan}

Pada langkah 2, lokasi survei dipilih untuk penilaian lapangan dari kawasan berpotensi cocok (berpotensi tinggi atau berpotensi) yang diidentifikasi melalui pemetaan kecocokan (Langkah 1). Pertimbangan tambahan mengenai aspek finansial, zona kawasan dan hak atas tanah kemudian digunakan untuk lebih jauh memprioritaskan lokasi lahan. Proses ini dirancang untuk dengan cepat mengidentifikasi lokasi-lokasi prioritas yang paling menjanjikan untuk kebutuhan proyek atau perusahaan tertentu, bukan untuk secara sistematis menilai semua kawasan berpotensi cocok. Faktor-faktor prioritas yang digunakan untuk mengidentifikasi lokasi mungkin berbeda di setiap wilayah di Kabupaten Enrekang secara umum dan Kecamatan Cendana secara khusus dan lokasi terpilih mungkin tidak mewakili semua kawasan berpotensi cocok yang diidentifikasi dalam langkah pemetaan kecocokan. Adapun pertimbangan Luas lahan mencerminkan kawasan yang berdekatan dengan lokasi berpotensi cocok, yang berdampak bagi keputusan pemerintah setempat, misalnya kawasan sekitar yang lebih besar dapat mendukung pabrik yang lebih besar dan lebih menguntungkan. Dalam penerapan metode ini, batas 
minimum 5.000 hektar dipilih berdasarkan preferensi ukuran minimal umum. Namun belum ada data mengenai luasan secara pasti perkebunan kelapa sawit yang ada di Kecamatan Cendana. Jika melihat pada aspek topografi, sebagian besar wilayah dengan jenis tanah aluvial hidromorf pada ketinggian 400-1000 m dpl dikategorikan sebagai lahan berpotensi cocok untuk perkebunan kelapa sawit di Kecamatan Cendana Kabupaten Enrekang. Pada peta kecocokan gabungan dengan peta geologi, peta topografi dan peta iklim, ukuran kawasan berpotensi cocok untuk lahan perkebunan kelapa sawit di Kecamatan Cendana cocok dihitung dengan GIS.

Pertimbangan selanjutnya adalah aksesibilitas yang menunjukkan seberapa mudah sebuah lokasi dapat dicapai melalui jalan darat atau sungai, yang berdampak pada berapa banyak investasi infrastruktur yang dibutuhkan untuk proyek serta kelayakan melakukan survei lapangan. Kemudahan aksesibilitas dapat meningkatkan daya tarik sebuah lokasi, walaupun perusahaan juga menyatakan kesediaannya untuk berinvestasi dalam infrastruktur bangunan setelah mendapatkan akses hukum atas tanah. Pada langkah ini, aksesibilitas dinilai dengan memeriksa peta kecocokan gabungan secara visual, ditambah dengan data spasial sungai dan jalan. Langkah ini juga bisa dilakukan secara otomatis dengan menggunakan GIS dalam menentukan syarat "jarak minimum ke jalan".

\section{Penilaian Lapangan}

Tahap ini mencakup pelaksanaan dan analisis survei lapangan dari lokasi prioritas yang diidentifikasi dalam tahap I, untuk memastikan atau mengeliminasi lokasi yang berpotensi cocok. Dalam tahap II, keseluruhan aspek yang digunakan dalam menganalisis serta mengindetifikasi, seperti aspek topografi, jenis tanah, geologi dan iklim setempat, turut mendukung lahan berpotensi cocok di Kecamatan Cendana sebagai lahan perkebunan sawit. Di setiap lokasi, tim lapangan mengumpulkan foto-foto arah penunjuk dengan koordinat GPS dan melakukan survei berdasarkan informasi yang dikumpulkan melalui observasi langsung di lapangan dan wawancara dengan warga setempat, termasuk Kepala Kecamatan Cendana Kabupaten Enrekang bernama Bapak Drs. H. Yunus Rajudding, MM., bertempat di Kantor Kecamatan Cendana Kabupaten Enrekang.

Analisis dan identifikasi tersebut kemudian diinformasikan pejabat pemerintah dalam menilai pilihan kebijakan untuk penggunaan lahan berkelanjutan. Langkah pertama dari proses ini, mengklasifikasikan luas total sekitar 100 hektar lahan berpotensi cocok di Kecamatan Cendana Kabupaten Enrekang. Sebagai perbandingan, para ahli telah memperkirakan antara 3 sampai 7 juta hektar lahan akan digunakan untuk ekspansi perkebunan kelapa sawit di seluruh Indonesia pada tahun 2020. Penilaian lapangan diperlukan untuk memastikan menerima atau menolak potensi kecocokan tiap lokasi.

\section{KESIMPULAN DAN IMPLIKASI PENELITIAN}

Laporan ini menunjukkan bagaimana cara untuk menerapkan interpretasi yang 
Hasriyanti, Ibrahim Abbas, M. Nur Zakariah Leo. Aplikasi Peta Jenis Tanah Dalam Mengidentifikasi Lahan Berpotensi Untuk Perkebunan Kelapa Sawit Di Kecamatan Cendana Kabupaten Enrekang

bisa dengan sederhana dan murah dalam mengidentifikasi kawasan-kawasan berpotensi untuk budidaya kelapa sawit. Hasil yang diperoleh dalam kegiatan ini menunjukkan bahwa ada sebagian besar lahan berpotensi cocok untuk budidaya kelapa sawit di Kecamatan Cendana Kabupaten Enrekang. Lanjut pada beberapa data yang menunjukkan bahwa pengetahuan masyarakat masih sangat kurang mengenai potensi lahan terhadap perkebunan kelapa sawit. Hal tersebut ditunjukkan dengan jumlah dan luasan lahan perkebunan kelapa sawit yang sedikit terdapat di Kecamatan Cendana, kondisi lahan yang tidak terawat baik meskipun sudah ditanami kelapa sawit. Masyarakat melalui pemerintah setempat, diberikan pengetahuan melalui aplikasi peta tematik jenis tanah dalam mengidentifikasi lahan berpotensi untuk perkebunan kelapa sawit. Meskipun kegiatan pengabdian ini hanya sebatas pada identifikasi sebagai tahap awal, diharapkan selanjutnya dilakukan penelitian melalui parameter fisik, kimia, dan biologinya secara mendalam.

Penerapan aplikasi peta tematik jenis tanah ini secara luas dikombinasikan dengan kegiatan yang tepat, begitu lokasi berpotensi cocok diidentifikasi dapat memberikan sumbangan bagi peningkatan produksi kelapa sawit berkelanjutan, pengurangan kemiskinan dan perbaikan pengelolaan sumber daya alam di Kabupaten Enrekang khususnya dan di Indonesia pada umumnya.

\section{DAFTAR PUSTAKA}

Abdullah, T. S., 1993. Survei Tanah dan Evaluasi Lahan. Penebar Swadaya, Jakarta.

Anonima. 2012. Pertanian lahan kering; Online: $\quad$ http://soil. $\quad$ faperta.ugm.ac.id/.pdf. Tanggal Akses 12 Maret 2012.

Darmawijaya, M. I., 1997. Klasifikasi Tanah. Gadjah Mada University Press, Yogyakarta.

Dejan Dragan, Tomaž Kramberger, Andrej Lisec, Marko Intihar, Klemen Prah. 2011. Using GIS for the Optimization of Pupils Transportation: The Case of Laško Municipality. Logistics \& Sustainable Transport. Vol. 2, No. 3, September 2011, 3551.

Djaenudin, D., Marwan H., Subagyo H., dan A. Hidayat. 2003. Petunjuk Teknis Evaluasi Lahan untuk Komoditas Pertanian. Balai Penelitian Tanah, Pusat Penelitian dan Pengembangan Tanah dan Agroklimat, Bogor.

Ekadinata, A., Dewi, S., Hadi, D. P., Nugroho, D. K., dan Johana, F. 2008. Sistem Informasi Geografis Untuk Pengelolaan bentang Lahan Berbasis Sumber Daya Alam. Word Agroforestry Centre: Bogor.

Foth, 1994. Dasar - Dasar Ilmu Tanah. Erlangga, Jakarta.

Harmon J. E., Anderson S. J. (2003). The Design and Implementation of Geographic Information System, John Wiley \& Sons, NY.

Jovanovic. 2010. The Aplication of GIS And Its Componen in Tourism.vanovic@singidunum.ac.yu Angelina Njeguš Faculty of Business Information Science.

Kartikasari, R. 2004. Klasifikasi Penutupan Lahan dengan Teknik Maksi- 
mum Likehood dan Fuzzy pada SPOT 4 Vegetation (Studi Kasus di Pulau Kalimantan) [skipsi]. Jurusan Manajemen Hutan, Fakultas Kehutanan, IPB: Bogor.

Lillesand, T.M., and Keifer, R.W. 1979. Remote Sensing and Image Interpretation. Third Edition. John Willey \& Sons, Inc: New York.

Lillesand, T.M., and Keifer, R.W. 1990. Penginderaan Jauh dan Interpretasi Citra. Terjemahan dari: Remote Sensing and Image Interpretation oleh Dulbahri et al. Gadjah Mada University Press: Yogyakarta.

Liptan, 1992. Budidaya Kelapa Sawit. Balai Informasi Irian Jaya, Jayapura. http://www.pustakadeptan.go.id/agritek/ppua0150.pdf.

Mukhlis, 2007. Analisis Tanah Dan Tanaman. USU press, Medan.

Muslihat, L., 2001. Evaluasi Sumberdaya Lahan Untuk Kelayakan Pertanaian Pada Lokasi Proyek Percontohan CCFPI Di Sumatera Dan Kaliman$\tan$. http://www.peatportal.net/view file.cfm?fileid=379.

Pahan, I., 2008. Kelapa Sawit: Manajemen Agribisnis Dari Hulu Hingga Hilir. Penebar Swadaya, Jakarta.

Rayes, M. L., 2006. Metode Inventarisasi Sumber Daya Lahan. Andi, Yogyakarta.

Rukmana, R., 1996. Durian: Budidaya dan Pasca Panen. Kanisius, Yogyakarta.
Rukmana, R. 1995. Teknik pengelolaan Lahan Berbukit Dan Kritis. Kanisius: Jakarta.

Sartohadi, Junun. ed. 2012. Pengantar Geografi Tanah. Yogyakarta: Pustaka Belajar.

Slavin, Robert E. 2000. Educational Psychology: Theory and Practice. Allyn \& Bacon. Boston.

Sunarko, Ir. 2007. Petunjuk Praktis Budidaya dan Pengolahan Kelapa Sawit. PT AgroMedia Pustaka. Jakarta.

Tan, K. H., 1998. Dasar - Dasar Kimia Tanah. UGM press, Yogyakarta.

Trubus, R., 2003. Mengebunkan Durian Unggul. Penebar Swadaya, Jakarta.

Untung, O., 2003. Durian: Untuk Kebun Komersial Dan Hobi. Penebar Swadaya, Jakarta.

Wahyuningrum, N., C. Nugroho, Wardojo, B. Harjadi, E. Savitri, Sudimin, dan Sudirman, 2003. Klasifikasi Kemampuan Dan Kesesuaian Lahan. Info DAS, Surakarta.

Wikipedia, 2009. Kelapa Sawit. http://id.wikipedia.org/wiki/Kelapa sawit. 